\title{
Federalism, Nigerian Federal Constitution and the Practice of Federalism: An Appraisal
}

\author{
Emmanuel Ibiam Amah \\ Faculty of Law, Ebonyi State University, Abakaliki, Nigeria \\ Email: amahibiam@gmail.com
}

How to cite this paper: Amah, E. I. (2017). Federalism, Nigerian Federal Constitution and the Practice of Federalism: An Appraisal. Beijing Law Review, 8, 287-310. https://doi.org/10.4236/blr.2017.83017

Received: June 17, 2017

Accepted: August 25, 2017

Published: August 28, 2017

Copyright $\odot 2017$ by author and Scientific Research Publishing Inc. This work is licensed under the Creative Commons Attribution International License (CC BY 4.0).

http://creativecommons.org/licenses/by/4.0/

\begin{abstract}
In 1954, the Nigerian founding fathers opted for a federal system of government despite its inherent challenges in a pluralistic society. This research work $\mathrm{x}$-rayed federalism in Nigeria as the only basis upon which Nigeria can remain united despite its diversity and peculiar conditions in which the different tribal groups live in and proffers solutions to the challenges of the practice of federalism in Nigeria. The greatest problem of federalism in Nigeria today is the general problems of the true nature of the federal relationship as manifested in the intense rivalry and confrontation between the Federal and State Governments. This work recommends that the calls for the restructuring of federalism in Nigeria under the 1999 Constitution (as amended) should be implemented and federalism demands of them co-operation with one another in order to promote the welfare of the people through their combined powers.
\end{abstract}

\section{Keywords}

Federalism, Constitution, Autonomy, Democracy

\section{Introduction: Meaning, Origin and Concept of Federalism}

Federalism is a system of governmental organization whereby two or more independent states agreed to form a common government while retaining their distinctive autonomy. It is a concept that attempts to give meaning to a form of government in which, rather than being concentrated in one body, is decentralized between the central authority and the component units that come together out of one or more significant reasons, and to which there exist a constitutional stipulation of the nature and period of exercising the specific power to avoid clashes and a provision for a means of compromise when clashes are inevitable. A federalism or federal principles, denote the division of law making authorities in a federal set up between the central authority of the federation and the au- 
thority of the components or units of government and the vesting of autonomy to each of these different governmental authority in such a way that none can interfere with the legislative authority of the other. The term federalism originated from a Latin expression pronounced "faedus" which refers to a covenant ${ }^{1}$. Federalism as a concept is traceable to the ancient twelve tribes of Israel and the league of Greek City States ${ }^{2}$.

Federalism as a political arrangement has faced serious crises of conceptualization. This is because in the words of Elazar ${ }^{3}$, There have been several varieties of political arrangement to which the term has been applied. Among the inherent challenges of conceptualization of federalism according to Rickar is that ${ }^{4}$ :

The meaning of the word has been thoroughly confused by dramatic changes in the institutions to which it refers. Hence, a word that originally referred to institutions with emphasis on self-government has come to connote also domination by a gigantic impersonal concentration of force.

However, most scholars of federalism have accepted Wheare's ${ }^{5}$ conceptualization of the subject matter as a point of convergence. Wheare' ${ }^{6}$ definition of the federal concept emphasized on an explicit division of powers and functions between a central government and some decentralized units government in such a manner that no government can encroach on the powers and functions of the other. This governmental division must be exercised by means of a rigid and written constitution that provides for an independent arbiter as well as financial autonomy for the respective governments. Thus, a comprehensive postulate of federalism is predicated on the existence of a constitutional division of powers of the federation between the central government and the units' government as well as a provision in the constitution for an independent arbiter for the purpose of settling constitutional disputes that might arise between the various government components of the federation; such a constitution being supreme providing and guaranteeing autonomy of the units and binding among all the members

${ }^{1}$ C. Chukwujekwu, "Historical Origin and Evolution of Nigeria Federalism" in Anthony et al. (eds) (2004) Federalism and National Integration in Nigeria (Onitsha Book Point Ltd, 2004) p. 19 cited in Amah (2016b), "Federalism, Democracy and Constitutionalism: The Nigerian Experience", Journal of Law, Policy and Globalization ISSN 2224-3240 (Paper) ISSN 2224-3259 (Online) Vol. 53, 2016, p.1. ${ }^{2}$ E.I. Amah, ibid.

${ }^{3}$ Elazar (1994), Federal System of the World; A Hand Book of Federal, Confederal and Autonomy Arrangements; Harlow, Essex: Longman, 1994, p.3 JCPA online

http://www.jcpa.org/dje/books/fedsysworld-intro.htm (accessed 12/07/17), cited in E.A. Obi "Issues in the Theoretical Foundations of Federalism" in O.E. Anthony et al. (eds) p. 19.

${ }^{4} \mathrm{~W}$. Rickar, cited in O.E. Anthony et al. (eds). op. cit. p 4.

${ }^{5}$ Wheare (1963), Federal Government ( $4^{\text {th }}$ ed. Oxford University Press, 1963) pp. 10-11. Jinadu however asserted that the crucial defect of Wheare's formulations of federalism is not that it is excessively legalistic. Its major weakness, rather, is that it stresses formal institutional requirements explicit; Constitutional delimitation of powers, bi-cameral legislature, independent electoral systems for both levels of government, multi-party but preferably a two-party system, a supreme court-as if they are defining characteristics of federalism or perhaps logically built into the meaning of federalism. Jinadu,however failed to proffer an alternate comprehensive construct of the concept. A.L, Jinadu $A$ note on the Theory of Federalism (1979) cited in O.E. Anthony et al. (eds) Op. cit., p.3.

${ }^{6}$ Wheare Op. cit. 
of the federation.

Federalism is a reflection of the inherent diversities in a society ${ }^{7}$. It is a system fashioned to hold different nations together in a state, while allowing each of them a degree of autonomy in certain areas.

There are two major theoretical conceptions of federalism; one conception regards federalism to be a uniting force or bond which results to the joining of different nationalities into a single statehood through the sharing of governmental administrative offices among them. This conception wherever adopted results to a virile and stable federal polity. The other conception regards federalism as a way of joining different nations with visible dissimilarities to form a single statehood with a much reduced objectives while granting the individual nations ample rooms to exist independent of the rest and exercising uninterrupted autonomy within their respective territorial jurisdiction while sharing together the reduced, concentrated and specified objectives. This particular conception may be more appropriately applied to the Nigerian federalism. However, this envisages the development of a limited central government.

The most fundamental thing about federalism is that there must be a constitutional division of powers between levels of government. The main essence of the principle of federalism is to maintain unity in spite of the cleavages among the diverse nations that have agreed to come together ${ }^{8}$. Federalism as a normative basis for a nation's socio-political structure would seem to be primarily a functional and pragmatic accommodation of the opposing principles of unity and separatism, integration and regional autonomy. This is based on the recognition of the need of national unity and a centralized system of governance, while acknowledging the differences, diversities and unique interests of the various federating units. This is because federalism as a system of government emanates from the desire of the people to form a union without necessarily losing their various identities. It is an attempt to reflect the various, diverse, social political, cultural and economic interests within the framework of a broader functional unity?.

The essential nature of federalism is a pragmatic distribution of power and resources by means of a Legal Document (a federal constitution) with a provision ensuring the impossibility of a unilateral abrogation of same by a member party without recourse to other members ${ }^{10}$. Other basic characteristics of a federal arrangement are fiscal autonomy, division of powers, a supreme constitution, and rule of law, democracy, and absence of marked inequality in population between regions. This research hereunder considers some of the basic features of federalism vis-à-vis the provisions of the federal constitution of Nigeria

${ }^{7}$ Livingstone (1952), “A Note on the Feature of Federalism" in Political Science Quarterly, Vol. LXII, Nos.1, March 1952.

${ }^{8}$ D.A. Omoweh, "Addressing the Needs of Oil Producing Areas within the Nigeria Federal Structure" in Ayua et al. (eds.) (2001), Political Return and Economic Recovery in Nigeria (Lagos: NIALS, 2001) p. 547.

${ }^{9}$ Wheare Op. cit. p. 33.

${ }^{10}$ E.I. Amah, Federalism, Democracy and Constitutionalism. Op.cit., p. 2. 
and the challenges to her practice of federalism. Before that however, we shall briefly consider the historical origin of federalism in Nigeria.

\section{Evolution of Federalism in Nigeria: Colonial Heritage}

It is well known fact that the contemporary limitations and contradictions inherent with the Nigerian federation have been heavily and directly molded by her colonial antecedents and further reinforced by her successive exposure to the negative impact of military dictatorship. The negative impact of colonialism was comparable to military autocracy ${ }^{11}$. It is therefore, logical to conclude that Nigerian federalism was created and nurtured under the influence of dictatorship and autocratic government. These therefore, perfectly explain the stunted and regressive nature of her federal cultures and practices. Federalism was introduced in Nigeria to forcibly unite the diverse ethnicities and nationalities that were previously arbitrarily amalgamated into a unitary colony and protectorates of the British Empire.

The Nigerian Federation has always had peculiar features; the most evident being that it was not created by the coming together of separate states but was the result of the subdivision of a country which had in theory been ruled as a single unit ${ }^{12}$. Earlier in 1951 the committee on the review of the Nigerian Constitution, had observed the unique nature of Nigerian federal concept and the peculiarities of her federal framework ${ }^{13}$. This form of federation is usually susceptible to the divisive influence of centripetal forces which tend to draw unhealthy loyalty to the components parts rather than loyalty to the national compact.

Devolutionary federations like Nigeria tend to lack the integrative identities and values of civic reciprocity and mutual respect associated with a voluntary compact or bargain to join a federal union ${ }^{14}$. The aftermath is the involuntary movement toward centralization as the state battles with dis-integrative forces. The resultant effect is a development toward over centralization or conversely toward secession. The implication and feature of "holding together" federations like Nigeria is that they tend to be more structurally and institutionally centralized, but less politically integrated and structurally coherent, than "coming together" federations. This is because the centrifugal forces are compulsive rather than voluntary. The British colonial legacy in Nigeria is said to be that of promotion of statehood and yet that of nation-destroying ${ }^{15}$. The British policy of di-

${ }^{11}$ Dudley (1973), Instability and Political Order: Political Crises in Nigeria, (Ibadan: Ibadan University press, 1973) p. 25.

${ }^{12}$ Mackintosh (1962), Federalism in Nigeria, Political Studies, 10, 3 (1962), p. 223.

${ }^{13}$ The Committee stated the federal governments of USA, Canada and Australia have been built on the basis of separate states surrendering to a federal government some of their powers for the benefit of all. The reverse process on which we are engaged-that of the creation of a federal government by devolution - is a political experiment for which... there is no precedent to guide us and we are very conscious of the dangers involved in such an experiment. See Nwabueze (2007), How President Obasanjo Subverted Nigeria's Federal System, (Ibadan: Gold Press Ltd, 2007) p.403.

${ }^{14}$ J. P. Mackintosh, Op. cit.

${ }^{15}$ Larry Diamond (1988), Class, Ethnicity and Democracy in Nigeria: The Failure of the First Republic. (London Macmillan press, 1988), p. 26. 
vide-and-rule system introduced in Nigeria operated to inflame division, suspicion, chaos and recrimination among the diverse ethnic nationalities that were flagrantly assembled into an unsuitably and superficial single, artifice called $\mathrm{Ni}$ gerian federation. It is of wide knowledge that the British colonial government through its system of divide and rule orchestrated by her indirect rule policy promoted and encouraged ethnic loyalty and consciousness. Regionalism as introduced by the colonial government heightens tribal sentiment, exacerbated minorities exploitation and domination and nurtured mutual suspicion and unhealthy battle and fight over federal power on ethnic and tribal and religious basis.

The 1954 Littleton Constitution ${ }^{16}$, constitutionalized regionalism by establishing for Nigeria a three-region federation. This capricious creation was in total disregard of the multi ethnic nature of the country. The three regional structures further institutionalized the political hegemony and demographic preeminence of the North over the two southern regions combined with total disregard of the minorities situated in this region. Amidst serious and furious protest of these minorities, the British colonial government adamantly resisted all calls for a further subdivision of the country so as to carter for the minority ethnic groups. This is in spite of the loud warning that a federal system in which one region had a population majority could be a potential cause of instability ${ }^{17}$.

As a result of these flawed and disjointed federal structure the federation could not endure long as immediately the British government left the political scene and relinquished control of the federation to the nationalists the federation could not withstand the tensions and quakes that culminated into the demise of the first republic and the eventual military takeover of government. The aftermath was the genocidal civil war of 1966 to 1979.

The intervention of the Nigerian military though applauded at the inception rather escalated overtime the existing inter-regional tensions into large-scale inter-ethnic violence and civil war and the following in balance associated with the federation. While state creation as a system of assuaging the demands of the minorities ethnic nations was a welcome development the resultant effect of state creation in Nigeria has produced negative consequences as it has benefited the majority ethnic groups more than the minorities and therefore could not assuaged the demands of the minorities scattered all over the federation. The corrosive and ruinous impact of military dictatorship to the seemingly federal Nigeria was markedly between the military coups that ended the Second Republic in 1983 to the end of Late General Abacha's dictatorial regime. The first phase of military rule between 1966 and 1979 is said to have been largely one of hegemonic exchange ${ }^{18}$. Thus, during this period the ruling military class acquired

\footnotetext{
${ }^{16}$ Udoma (1994) History and Law of the Constitution of Nigeria (Lagos: Malthouse Press Ltd.,) p. 7, C. Chukwujekwu, Historical Origin and Evolution of Nigerian Federalism, in Anthony \& Obiajulu (eds.) (2004) Federalism and National Integration in Nigeria, (Onitsha: Book Point Ltd.) 19, Nwabueze (1995), Constitutional History of Nigeria (Spectrum Books Ltd.) 1995, p.11.

${ }^{17}$ Ibid.

${ }^{18}$ Donald Rotchild, State-Ethnic Relations in middle Africa, in Gwendolen and Patrick (1985), eds. African Independence: the First Twenty-Five Years. (Bloomington, in Indianan University Press, 1985) pp. 71-96.
} 
some degree of consent from the Nigeria populace as military rule was seen as a necessary intervention to right the wrongs of the supposedly irresponsible political class. At this period in which the central military government gave free hand to the military administrations-in the states to exercise most of these functions constitutionally apportioned to the regional governments as well as appointed credible and influential civilian political elites on ethnic and religious considerations into various ministerial positions, and initiated and implemented a fairly successful programme of re-democratization which culminated in the inauguration of the Second Republic in October 1979.

In contrast to the first phase of military rule, the second phase of military rule featured excessive abuse of power, personalization and concentration of machinery of government in the military head of state; an increasing domination and repression of ethnic minorities and promotion of northern hegemony, total and flagrant disregard of re-democratization movements, and the manipulative and repulsive concentration of government at the centre with no regard to federal ideal, principles and practices. There was therefore total collapse of federal structure and governance as fiscal federalism was a pariah doctrine. The more prominent examples of such over centralization include: the complete subordination of constituent state governments to the unified military command system via the centre's appointment' and frequent redeployment of relatively junior officers as state governors or administrators; the direct action of the Army in destabilizing local government councils by means of their incessant acts of re-organization of the local government administration; the continued overwhelming, indeed near-total, dependence of the states and localities on central funding; the systematic (and apparently unchallengeable) manipulation of statutory intergovernmental revenue-sharing arrangements in a manner that reinforced the financial dependencies of the constituents states of the federation, the complete castration of the autonomy of the judiciary by means of ouster clauses which aberration prevented this arm of government from playing its normal federalist role in arbitrating intergovernmental constitutional disputes; and the proliferation of new units of centrally-funded states and local governments as part of a strategy to consolidate the centre's domination and promote the continuity and legitimacy of military rule.

Military incursion in Nigeria unarguably left Nigerian federalism traumatized, violated and stunted. Federal Institutions, structures and framework suitable for a multi ethnic pluralist polity like Nigeria were weakened if not entirely destroyed. Opposition which is part of the pillar of good governance in the civilized world was silenced. Rather than promote local autonomy and diversity military rule sought to weaken dissent in the belief that only in so doing can the state be strengthened ${ }^{19}$. It is these weak institutions that the present State of $\mathrm{Ni}$ geria inherited.

${ }^{19}$ On the Philosophical basis of this phenomenon, see Dudley (1975), "Skepticism and political Virtue" Inaugural lecture, University of Ibadan, 1975, p. 21. 
Without doubt, federalism holds the key to a stable and stronger Nigeria. True federalism has not been practiced in Nigeria and this explains her onerous challenges till date. It seems obvious that much of the agitation for the dissolution or confederalisation of Nigeria is often inspired not by a lack of faith in a virile federal state of Nigeria per se, but because of the dissatisfaction or frustration with the inequities and abnormalities that characterized the current practices of federalism in Nigeria. Before we proffer solution let us further consider the federal features contained in her Constitution and the seeming flaws that have hindered her inability to practice true federalism.

\section{Nigerian Constitution and the Challenges to the Practice of Federalism}

Following the provisions of section 2(1), (3) of the 1999 Constitution of the Federal Republic of Nigeria; Nigeria is a federation consisting of thirty six states and a Federal Capital Territory. The federal arrangement in Nigeria under the constitution is premised on a distinctive division of powers of the federation between the central (federal) and the States' governments. This involves the sharing of powers between the federal government and the state governments to foster easy administrations, cooperation and promote the principles of separation of power. It therefore appears that the basic goal of federalism in Nigeria is to promote the unity of the country while creating space for political autonomy of the different sections of Nigeria ${ }^{20}$. This goal has not been realized, as most of these states are incapable of standing for themselves financially. The balkanization of the federation into several states' units has created excessive dependence on the central government thereby derogating from the very tenet of federalism. While creation of states could be a means of securing self-determination of the minority ethnic groups in Nigeria in practice the majority ethnic groups have benefited much more from state creation to the disadvantage of the minority groups. As a result, agitations for creation of states have not abated as many ethnic groups have continued to demand for their own states. Creation of states has not solved the problems of Nigerian federation as it has rather created more problems owing to none viability of these states in terms of resources. We shall hereunder consider other challenges associated with her federal Constitution and practices.

\subsection{Nigerian Federal Constitution and the Amendment Process}

Federal constitutions are usually rigid in nature. In another sense its amendment requires a special procedure enshrined into it. The reason is to prevent any level of government from abusing the provision of the constitution. This special procedure is couched in the nature of "entrenched clauses" and the constitution can only be altered or changed using the prescribed procedure ${ }^{21}$.

\footnotetext{
${ }^{20}$ E. I. Amah, Federalism, Democracy and Constitutionalism. Op. cit. p. 6.

${ }^{21}$ Igwenyi (2006), Modern Constitutional Law in Nigeria (Abakaliki: Nwamazi Printing and Publication Company Ltd, 2006) p. 21.
} 
The Nigerian constitution contained a special procedure for its amendment as contained in Section 9. Thus, to amend any provision of the Nigerian Constitution, it is not only that votes of at least two-thirds majority of members of the House of Representatives and the Senate (National Assembly) ${ }^{22}$ must support such proposal, the amendment must be approved by resolution of not less than twenty-four (24) State Houses of Assembly out of the present thirty-six (36) States of the Federation. Where the amendment touches on Section 9 (dealing with amendments procedure) or Section 8 (touching on creation of States) or Chapter 4 (dealing with fundamental human rights), stricter condition of fourfifths majority of the State Houses of Assembly nationwide is required.

The rigidity of the constitutional amendment procedure arises from diverse reasons e.g. where the Legislature is expected to adopt special majority before an alteration can occur (like the case of Nigeria) or where an outside body or agency has to take part in voting to ratify that change (e.g. in the case of Houses of Assembly of the states of the federation passing resolution) or where the amendment has to be approved through referendum after initiation of the alteration by the Parliament (as in the case of boundary adjustment or creation of additional local government councils $)^{23}$ aimed at fostering and fastening the federal idea.

While rigidity in an amendment process could check arbitrariness and ensure minority right protection, undue rigidity may as well be a means of shutting out opposition and fostering majority domination in a pluralistic federal society. An amendment procedure such as in the case of state or additional local government creation, which requires input from the affected states or local government councils as the case may be will surely deny legitimate demand from a group for additional states or local government councils. This fact is demonstrated by the absolute difficulty that has followed every attempt to create additional local government councils or states in Nigeria under a democratic government. In the recent past following the provisions of the constitution on local government council creation some States' Houses of Assembly purported to create additional local government councils, these moves were frustrated by the federal government taking advantage of the special procedure enshrined in the constitution for such amendment. Further referendum should be incorporated to form part of the constitutional amendment process. The absence of provision for referendum in the constitutional amendment has deprived Nigerians of the opportunity of effecting constitutional changes by popular votes. Modern government and advanced democracies thrives on the employment of referendum, a form of direct democracy which gives the people the opportunity of deciding political and national issues on the basis of voting in favor or against specific matters ${ }^{24}$.

\footnotetext{
${ }^{22}$ The National Assembly is made up to 360 members of House of Representatives and 109 Senators totaling 469 as provided under section 49 and 48 respectively.

${ }^{23}$ Section 8, Constitution of the Federal Republic of Nigeria, 1999.

${ }^{24}$ See Amah (2017) "Nigeria: the Search for Autochthonous Constitution", Beijing Law Review, 8, 141158. https://doi.org/10.4236/blr.2017.81008
} 


\subsection{Division of Powers under the Nigerian Federal Constitution}

The constitutional sharing or division of the governmental powers between different levels of government and amongst component units markedly differentiates federalism from other forms of governmental organizations. The existence of different levels of government therefore, demands that power is shared among them to prevent one level from encroaching on the powers of the others thereby checking undue rivalry ${ }^{25}$.

Some scholars favoured reposing predominant powers and functions on the central governments while others advocated granting equal powers and function to all the member components of the federal union ${ }^{26}$.

Constitutional division of powers and functions is aimed at preventing abuse of governmental powers. The rationale behind the idea of division of powers in a federal state is that matters of common interest and concern to the country as a whole should be allocated to the Central Government while matters that are local in nature should be allocated to component states government ${ }^{27}$. The constitution in this manner is to make provision for some degree of autonomy among the different components members of the federation, without though ignoring the need for interdependence, coordination and harmonious existence.

Under the 1999 Constitution, powers are classified as Exclusive and Concurrent Legislative Powers ${ }^{28}$. The Exclusive Legislative List has 68 items ${ }^{29}$; such as aviation, banks, bills of exchange, census, citizenship, copyrights, currency, custom and excise, defence, diplomatic relations, foreign affairs, immigration and emigration, incorporation of business associations, insurance, labour, shipping, armed forces, communication, prisons, railways, taxation, trade and commerce, weight and measures, wireless broadcasting and so forth, while, the Concurrent Legislative List has 12 items $^{30}$. The authority to legislate on the Exclusive Legislative List is exclusively vested in the Federal Government and the States may legislate on the items specified in the list only to the extent expressly authorized by a Federal Law. It is however to be observed that the Exclusive legislative list is unnecessarily numerous and contained matters which ordinarily should be placed under the jurisdiction of the federating units. Example of these items is land. Land is under the exclusive legislative list even though by virtue of the Land Use $\mathrm{Act}^{31}$ land is vested on the state government. Others include: Drugs

${ }^{25}$ D. J. Elazar, cited in Amah (2016a), "A Critical Appraisal of the Federal features of the Nigerian Constitution”, Ebonyi State University Law Journal Vol. 7, No 2, 2016, p. 122.

${ }^{26}$ See M.O. Adediran, "Critical Examination of the Constitutional Provision on the Legislative power of the Federal and States" being a chapter in Proceeding of the Conference on the 1995 Nigerian Constitution edited by J.O. Ojo at p.11, Nwabueze (1973), Nigeria under the Presidential Constitution (UK: C. Hurst \& Co. 1973) p. 182.

${ }^{27}$ Elaigwu, Longams, \& Galadima (2008), Federalism and Nation Building: publ: National council of inter.p. 66, cited in E. I. Amah, "Federalism, Democracy and Constitutionalism", Op. cit. p. 6.

${ }^{28}$ Nwabueze (1983), Federalism in Nigeria, (London: Sweet and Maxwell, 1983) p. 41.

${ }^{29}$ E. I. Amah, Federalism, "Democracy and Constitutionalism", op. cit. p. 6.

${ }^{30}$ Second Schedule Part I and Part II to the 1999 Constitution as amended.

${ }^{31}$ Land Use Act 1978, Cap. L5 L.F.N. 2010. 
and poison, fishing and fisheries, labour and minimum wage, mines and minerals including oil fields, oil mining geological survey and natural gas. Trade and registration of business names, police, post, telegraph and telephones, prisons, taxation, marriages, education etc. these items could conveniently be managed by the states being matters of local concern.

The Federal Government and States Governments both have powers to legislate on matters specified in the concurrent list, however, if any law made by the House of Assembly of a State is inconsistent with any law validly made by the National Assembly, the law made by the National Assembly shall prevail and that other law (made by the State) shall be void to the extent of its inconsistency with the federal law ${ }^{32}$. Thus under Concurrent Legislative List also, the federal government still possesses an overriding power over the state governments by virtue of the overriding clause $\mathrm{s}^{33}$. The effect is that the states are deprived of the viable portions of the federation resources thereby making them dependent on the federal government at the centre.

It is further to be noted, that the Fourth Schedule of the 1999 Constitution provides the list of functions of the local government councils in Nigeria, that is, the third tier of government in Nigerian federal arrangement. However, it did not expressly or by implication conferred any legislative functions on the Local Government Councils ${ }^{34}$. The councils are therefore an appendage of the state governments and it is within the powers of the state house of assemblies to make law regulating these councils. It is this basic feature that deprives the local government councils of its autonomy as the constitution vested its creation and finance on the states governments.

\subsection{Democracy}

Democracy is a system of government under which the people exercise their governing power either directly or indirectly through representatives periodically elected by them. Democracy as a concept is a set of ideals, institutions and process of governance that allow the broad mass of the people to choose their leaders and that guarantees them a broad range of civic rights. It has been defined as the government of the people, by the people and for the people $e^{35}$.

Federalism thrives on democracy and can hardly survive independent of democracy. Thus federalism is inherently democratic ${ }^{36}$.

Democracy and federalism are of importance to the social and political phenomena in a given country that practice it. While federalism ensures that the 
democratic powers are shared between levels of government in a given polity, democracy aims at ensuring that the will of the majority (the electorates) is carried out in that polity while recognizing minority interests. As a result of the above, sharing of power in a large and heterogeneous nation is a possible way of ensuring democratic rule. Federalism facilitates the practice of democracy, so also does democracy to the practice of federalism; Federalism cannot thrive in the absence of democracy. Federalism affords citizens, multiple points of access, thereby enhancing opportunities for public participation, increasing the accountability and responsiveness of elected officials to the electorates and hence providing incentive for more responsive democratic government. In the broadest sense, federalism involves the linking of individuals, groups and polities in lasting but limited union in such a way as to provide for energetic pursuit of common ends while maintaining the respective integrities of all parties ${ }^{37}$. Democracy holds out promise of nationalism and self-determination to the federal components whereas such promise is more easily endangered in a non-democratic federal system.

Democracy as a concept involves such variables as an enabling constitutional order, political parties, and institutions like the electoral commission, tribunals etc. ${ }^{38}$ Other variables include the electorates, political actors, voting behavior, political culture and political leadership ${ }^{39}$. A good democracy must provide an enabling environment in which these variables must thrive and subsist ${ }^{40}$.

In a heterogeneous society like Nigeria, democratic rule should embrace the wishes and aspirations of the diverse nationalities that make up the nation. Democracy in practice has not thrived well in Nigeria. Elections have been consistently marred by violence, thuggery, ethnic sentiment rigging and ballot snatching. Elections officials are bribed while law enforcement agents take sides with the ruling party. Politicians have constantly turned to the election tribunals to ventilate their grievances and many elections results have been cancelled by the courts and tribunals. Election rigging undermines the cardinal principle of democracy, namely the will of the people. On the other hand, ethnic politics tend to produce political actors whose motivation had sectional rather than national calculations. The resultant effect is the growth of subgroups sentiment, which tends to becloud national interest.

\subsection{The Judiciary under Nigerian Federation}

The judiciary is often seen as the most crucial arm of government because of the invaluable role it plays in determining rights, responsibilities and obligations between persons, institutions and the government. In tandem with this fact, Nnamani JSC ${ }^{41}$ described it as the guardian of the constitution and fundamental

\footnotetext{
${ }^{37}$ E. I. Amah, Federalism, Democracy and Constitutionalism. Op. cit., p. 12.

${ }^{38}$ Ibid.

${ }^{39}$ Ibid.

${ }^{40} \mathrm{Ibid}$.

${ }^{41}$ B.O. Igwenyi, Op. cit., p. 275.
} 
rights and the protector of governance; the maintainer of public order and public security among other functions.

This view encapsulates the very essence of this branch of government especially under the practice of federalism. The judicial arm of government in Nigeria is vested with judicial power under Section 6(1) (2) and (3) of the 1999 Constitution of the Federal Republic of Nigeria (as amended) which states;

(1) The judicial powers of the federation shall be vested in the courts to which this section relates, being courts established for the federation.

The judicial powers of a state shall be vested in the courts to which this section relates, being courts established, subject as provided by this constitution, for a state.

(3) The courts to which this section relates, established by this constitution for the federation and for the states, specified in subsection (5) (a) to (i) of this section shall be only superior courts of record in Nigeria; saves as otherwise prescribed by the National Assembly or by the House of Assembly of a State, each court shall have all the powers of a superior court of record.

Subsection 4, further provided for such other courts as may be authorized by law to exercise jurisdiction at first instance or on appeal on matters with respect to which the National Assembly and House of Assembly may make laws respectively. Judicial power is nowhere defined in the constitution but the Supreme Court of Nigeria in the case of Senator Abraham Adesanya $v$ President of the Federal Republic of Nigeria ${ }^{42}$, defined judicial power thus: The words "judicial powers" as used in the constitution means the power which every sovereign authority must of necessity have to decide controversies between its subjects, or between itself and its subjects.

The scope of this power given to the Nigerian Courts is so wide that it covers judicial review of the acts of the other arms of government. The exercise of such powers can be seen in the line of cases such as Attorney-General of Lagos State v. Attorney-General of the Federation ${ }^{43}$; Attorney-General of Abia State v. Attorney-General of the Federation ${ }^{44}$; Attorney General of Ondo State v. AttorneyGeneral of the Federation ${ }^{45}$; Attorney-General of Bendel State v. Attorney-General of the Federation ${ }^{46}$ etc.

The Nigeria courts have of recent been accused of corruption. The institutionalization of corruption in the judiciary finds ready expression in the manifest reluctance of members of the bench to give any judgment against the government of the day ${ }^{47}$. Corruption in the judiciary erodes public confidence and undermines good governance.

42(1981) 5 S.C. 112; (1981) 2 NCLR358.

${ }^{43}(2003) 12$ N.W.L.R. (Pt. 833) p.1.

${ }^{44}(2002) 6$ N.W.L.R. (Pt. 763) p. 264.

${ }^{45}(2002)$ 9. N.W.L.R. (Pt.772) p.222.

${ }^{46}(1981) 10$ S.C, p.1.

${ }^{47}$ Nwabueze, Ideas and Facts in Constitution Making (Spectrum Books Ltd, Ibadan, 1993) p. 212. 


\subsection{Fiscal Federalism/Financial Dependence of States on the Centre}

Federalism learns in favour of financial autonomy, which include the autonomy of the component units to have sufficient measure of control over resources accruing to and derivable from area of their individual territory ${ }^{48}$. Wheare ${ }^{49}$ had emphasized on the need for financial independence or autonomy of each of the constituent units of government in a federal order and their unrestrained liberty to pursue their respective development without depending on the other(s) constituent units for aid. The principle of fiscal federalism requires that both the federal and state governments should each have its own relevance base firmly founded on independent revenue resources, so that one should not be a beggar to the other, in other to create a sense of fiscal responsibility so essential to the efficient generation and management of public revenue ${ }^{50}$. More importantly, because in a country with a federal government, its lower tiers of government be it states, regions or local government are deemed to be autonomous and enjoy some degree or medium of independence in their area of competence, federal relations must therefore replicate fiscal autonomy ${ }^{51}$.

The structural imbalance in resource distribution in the inter-state relations in Nigeria is a sore area. In Nigeria federalism, the central government has been by far the most powerful, the strongest and the most financially solvent. The 1999 Constitution have therefore provided for certain federal features, the principle of financial autonomy was not adequately provided, therefore at the ending of every month, each State Government in Nigeria has to wait for its own share of the federal allocation from the Federation Account. In recent times, the Accountant General of the Federation has had cause to withhold the allocation accruable to some States of the Federation on the instruction of the Federal Government ${ }^{52}$. The constituent States mainly rely on monthly handouts called "Allocations" from the center for their survival. This has been further compounded by the change from agricultural export based economy to oil revenue. The Constitution of 1960 unlike the 1999 Constitution was favourably disposed to federalism by granting the regions financial autonomy. By this principle, the regions were meant to retain greater percentage of revenue that accrue as a result of revenues generated from their respective areas which led to spate of developments recorded by the various regional governments in the First Republic because they became viable enough to sustain and maintain their financial obliga-

\footnotetext{
${ }^{48}$ E.I. Amah, A Critical Appraisal of the Federal features of the Nigerian Constitution, Op. cit. p. 124, see also E. I. Amah, "Federalism, Democracy and Constitutionalism", op. cit. p.2.

${ }^{49}$ K.C. Wheare Op. cit.

${ }^{50}$ Report of the Technical Committee on Revenue Allocation (The Aboyade committee) 1977, vol.1, p.81 cited by Mohammed Bello, A Nigerian Essay in Jurisprudence in T.O. Elias et al. (eds.) (Lagos: MIJ Professional Publishers Ltd, 1993) p. 125.

${ }^{51}$ G. O. C. Ihebom, "Fiscal Federalism in Nigeria: A Comparative Analysis". Journal of Commercial Law and Contemporary Law (JCCL) of the Department of Commercial Law, Faculty of Law Imo State University. Vol. 1, June 2011, p. 46.

${ }^{52} \mathrm{Amah}$ (2013), "Federalism and the Issue of Resource Ownership and Management: An Appraisal", Confluence Journal of Jurisprudence of International Law Vol. 6 No. 2 2013, p. 50.
} 
tions. A constitutional restructuring is therefore essential so as to provide for financial autonomy of the states of the federation.

\subsection{Ethnicity, Diversities \& Rivalries}

Ethnic groups are social formations distinguished by the communal character of their boundaries, the relevant communal factors being language and culture ${ }^{53}$. Ethnicity has played a rather dominant role in the public life of Nigerian federation. So much has been tied to it in the national consciousness, including the availability of public offices, benefits, patronage etc, that, the moment somebody gets into public office (whether elected or appointed), it is perceived as the much needed opportunity for members of his or her ethnic group to have access to the nation's resources, or what has been termed in local everyday parlance, "the national cake". There is the intense struggle by the diverse ethnic or cultural groups dominantly the major ethnic groups such as the Hausa/Fulani; Igbo and Yoruba that make up the federation of Nigeria to control power at the federal level and to use such power for their ethnic benefits rather than for all members of the federation. Taking control of governance at the centre is therefore publicly viewed as a necessity in order to correct dislocations in the economy.

Opposition to successive governments has often been propelled by ethnic sentiments, or at any rate, has been fuelled by the machinery of ethnic violence, sometimes leading to insecurity and instability in the polity and their attendant consequences. So endemic have some of these ethnically motivated activities been that devices such as rotation of elective political offices among geopolitical groups or zones, a quota system of admission into public educational institutions, the principle of federal character, have been suggested or adopted as panacea to the dislocation with the polity. These intense struggles can be seen in the reaction of the Yoruba nationality to the annulment of the Presidential election of June 12, 1993 and the tyranny rule of Sani Abacha Military regime, which led to an irredentist struggle against the Federalist Statecraft. For them, it was as much a struggle also for democracy as it is for a restructuring of the Yoruba nation.

In the case of the Igbo nationality, the issue of social injustice resulting from the after-effects of the Biafra secessionist project and the civil war that followed (1967-1975) have drawn their attention to the absence of proper accommodation for them in the federation in terms of employment, economic opportunities, infrastructural development, politics, their inherently human and group freedom as well as constitutional rights to settle down in any part of the country for peaceful transaction of business ${ }^{54}$. Another major constraint which undermines the federal structure as enunciated under the 1999 Constitution is the issue of presidential election, where the zone of presidential aspirant is weightier than his

${ }^{53}$ Nnoli (1980), Ethnic Politics in Nigeria (Enugu: Fourth Dimension Publishers, 1980) p. 5.

${ }^{54}$ I.A. Ayua et al. (ed) Nigeria: Issues in the 1999 Constitution (Lagos: Nigerian Institute of Advanced Legal Studies, 2000) p. 121. 
ability to lead the nation. The popular and age-long old perception of the Nigerian political process has been that the North had been the unduly dominant beneficiary of federal resources because of this, any ethnic groups that secure the control of federal power interprets and applies the federal power and resources as it benefits them.

\subsection{Military Incursion}

The military incursion into politics in 1966 to 1979 and also from 1983 to 1999 did not fare well for the federal status of the nation. The military traditionally operates on unified command structure being an institutional undemocratic regime with a hierarchal chain of command which weakened the powers and autonomy of the constituent units and concentrated power and resources at the federal level. This replaced a truly federal structure with quasi unitary structure, more for administrative and political maneuvering than for the unity and wellbeing of the country ${ }^{55}$. This unjust structure has persisted over the years, even during civilian governments, because it has apparently favoured those ethnic nationalities that have monopolized the levels of power ever since. This led to over centralization of power and resources in the federal government which is perhaps the most widely lamented feature of the Nigeria federal system today. Another institutional injustice established by the military regimes against the healthy operation of federalism in Nigeria is the unitary feature of the 1999 Constitution of the Federal Republic of Nigeria (as amended) which is a carryover of 1979 Constitution.

\subsection{Religious Crisis and Intolerance}

Religious tension, conflict and violence in Nigeria have always been caused by the deliberate manipulation by some influential leaders such as the introduction of Sharia Law and Sharia Courts and the purported membership of the Organization of Islamic Conference ${ }^{56}$ by Nigeria (December 1985/January 1986) under the then Head of State, General Badamosi Babangida. Religious sentiments and activities have played an important role in obstructing the progress of federalism in Nigeria even though, from independence till date, Nigerian presidential election has maintained Moslem/Christian balance to assure on the safety of the multi-ethnic and plural Nigeria ${ }^{57}$.

The state of insecurity created by insurgency of Boko-Haram, Fulani herdsmen, Muslim/Christians crises, etc is a clear breach of the fundamental rights enshrined under the Federal Constitution such as: right to freedom of religion

${ }^{55}$ C.A. Obiora, "Federalism and Democratic Rule in Nigeria", being a chapter in E.A. Obi, et al., $\mathrm{Fe}$ deralism and National Integration in Nigeria. (Onitsha: BookPoint Ltd, 2004) p. 52.

${ }^{56}$ O.I.C. A body set to promote Islamic Solidarity among Member States.

${ }^{57}$ For example, the Obasanjo administration was a combination of a Christian President and a Muslim Vice President, the late Yar'adua administration maintained a Muslim President with a Christian Vice President while the Jonathan administration had a Christian President with a Muslim Vice President and presently the Buhari administration has a Muslim President with a Christian vice President. 
and worship ${ }^{58}$; right to life ${ }^{59}$; and right to privacy ${ }^{60}$. And such religious crises by fanatics have resulted in loss of lives, displacements of people and destruction of properties worth billions of Naira. The frightening aspects of this religious crises is that the federal government lacks the urgency, sincerity and resources (security prowess) to deal with it, these have not only affected the citizens of Nigeria but also foreign investors to shun and withdraw from investing in the economic sector provided by the various governmental fiscal and legal instruments.

\subsection{Marginalization of Ethnic Minorities}

This is another prominent feature of the crisis in Nigerian federalism, which is quite in accordance with the foundation laid for the federation by the Colonial Master. Some communal groups has been exploited and suppressed by other dominant groups. Related to this, is the problem of the oil producing communities where there exist resentments about distribution of oil revenues and under development of such communities. For example, the Niger Delta minority illustrates the point very well. This resentment took different and varying forms and this resentment had been manifested against the federal government in different periods as the oil producing communities' demands that ownership and management of these resources be vested on them to enable them carter for the resultant consequences of degradation and pollution of their environment ${ }^{61}$. There have been struggles and calls for compensation for environmental degradation and hazards caused by oil exploration, economic empowerment and development for the communities, increased allocation of federally collected revenue to the states and communities based on the principle of derivation and greater political and fiscal autonomy. This have gone to the extent of the oil producing communities pressing for the amendment of the Nigeria Constitution with a view to reviewing the ownership and control structure of the mineral resources in the country and the formula for sharing in the minerals wealth which will be in their favour ${ }^{62}$.

\subsection{Inefficiency of the Federal Character Principle and Its Implementation}

The principle of federal character was formulated by the Constitution Drafting Committee (CDC) which drafted the 1979 Constitution of the Federal Republic

\footnotetext{
${ }^{58}$ Section 38, the Constitution of the Federal Republic of Nigeria, 1999.

${ }^{59}$ Section 33 , ibid.

${ }^{60}$ Section 37, ibid.

${ }^{61}$ See Darah (2003) “The Niger Delta Manifesto", Paper presented for the Delta Peoples Academy Abraka Delta State, at the 3rd All Nigeria Socialist Conference, Benin City, February 20-22, 2003; Anam-Ndu (2007), "Fiscal Federalism, Resource Control and Violence in the Niger Delta", being text of paper presented at Center for minority and development studies, Uyo, at the National Association of Seadogs' Town hall meeting held at Eden Hotel, Eket on Saturday May 5, 2007.

${ }^{62}$ Alameyeseigha (2005) "Oil Exploration and Youth Restiveness, the example of Balyelsa State", reported in Tell Magazine No. 16 April 18, 2005, p. 13., A. George, "Nigerian Fiscal Federalism seen from a Comparative Perspective”, being an address to Governors Forum, Abuja, Nigeria, $28^{\text {th }}$ October, 2007 p. 3.
} 
of Nigeria and put into use by the government to address and hopefully mitigate the problem of acrimonious existence among the diverse groups and interests in the Federation of Nigeria which is endemic in the nation's body-politic and militates against the political stability of the country since independence leading to mutual distrust and inter-community conflict. According to Saro-Wiwa ${ }^{63}$, the formula will make for a more equal federation to which more people will owe loyalty because they see themselves represented meaningfully therein.

Thus, to resolve these issues and to ensure structural balance of claims and gains by the various groups and interests in Nigeria, the federal characters principle's application became imperative as a Directive Principle of State Policy under Section 14 (3) and (4) of the 1979 Constitution which is in pari materia with Section 14 (3) and (4) of the 1999 Constitution (as amended). This though, being non-justiciable provides some frameworks by which citizen are to live, requiring the governments and its machineries to refrain from doing things in a certain way.

To ensure the smooth application and operation of the federal character principle, create a sense of belonging and hope in all Nigerians and strengthen the Nation's unity and stability, the 1995 Draft Constitution went further to provide for a Federal Character Commission. This Commission is established by Section 153(1) (c) of the 1999 Constitution and is further provided in the Third Schedule Part I to the 1999 Constitution (as amended). The Commission is empowered to work out an equitable formula for the distribution of all cadres of posts; to monitor, promote and enforce compliance with the principles of proportional sharing of posts at all levels of government; and to take measures to prosecute heads of any government ministry, body or agency who fail to comply with the formula. The inefficiency of the Federal Character Commission to implement the provisions of the federal character principle is obvious, going by the inequalities or imbalance and marginalization witnessed in the political, cultural and socioeconomic sectors of the country. Furthermore, the federal character principles has been manipulated by and channeled to serve the overall interest of the bourgeois class. Under the guise of the federal character principle, the members of the bourgeois class get themselves entrenched in power and exercise control over the machinery of state. Gboyega ${ }^{64}$ rightly observed that it is an elite ploy which would not materially improve the lot of the downtrodden in whose name it is raised.

Under these circumstances, there is bound to be acrimony and socio-economic conflict between the haves (represented by the ruling elite class) and they have not (represented by the masses). Unless the interests of the masses are taken care of in the application of the federal character principle, in such a way, that they have access to the basic necessities of life, the formula is bound to have little or no relevance to the integration problems of Nigeria. Unfortunately, also, this

\footnotetext{
${ }^{63}$ Saro-Wiwa (1985), The Guardian: January 22, 1985, p. 7.

${ }^{64}$ A. Gboyega, "The Public Service and Federal Character", in Ekeh et al. (ed.) (1989) Federal Character and Federalism in Nigeria (Ibadan: Heinemann Books Nigeria Ltd, 1989) p. 183.
} 
principle while stressing the imperative of ethnic-balancing invariably enthrones ethnicity and de-emphasizes the Nation statehood. In the process, it strengthens the parochial, particularistic orientations and primordial ethnic attachments of Nigerians ${ }^{65}$. As a result, the federal character principle has deepened the problem it was devised to tackle ${ }^{66}$.

\subsection{Materialism}

The placing of money as the ultimate achievement to be fulfilled by the elected leaders and citizenry has resulted in the excessive pursuit of material wealth at any cost including compromising the federal principles. For instance, several probe reports and policy executions have shown that the ultimate goal in executing many federal and state projects is to make personal profits by some officials of the federal and state governments. This has been clearly shown by the recent exposure and recoveries of huge sums of money and confiscation of properties of past leaders, both at the Federal, State and even Local levels. Public servants and officials in governmental institutions such as ministries, agencies, departments and corporations are not free either from the menace of corrupt practices that undermine the common goals of a Federal State. Corruption in Nigeria is traceable to the advent of military in the Nigerian political life. Having entered the stronghold of power through unconstitutional and corrupt means, the military men in power sought to hold on to power at all cost. Since their rule was perceived to be unconstitutional, they sought ways of legitimizing their reign and by so doing looked towards the law courts to achieve what the barrels of their guns could never achieve for them. The military further introduced corruption to the police force, the government ministries and parastatals.

\subsection{Poverty}

Finally the issue of democracy and political participation lies not merely in the provisions in the constitutions but in the actual working of the constitution. It must be noted that in any political community where the barest essentials of life are absent, where food, health, and shelter are available below subsistence level that, citizens will be so pre-occupied with how to get these essentials that they may not bother about who governs or whether or not political actors play the game according to the rules. Political life will tend to be more individualistic than collectivistic. On the other hand, in a federal state like Nigeria, where these essentials are to be available in a lope sided manner, the units that are relatively in abject want will tend to be apolitical, apathetic and negative in their supportive responses.

The founding fathers of the United States wisely interpreted liberty widely to

${ }^{65}$ C.C. Agbodike, "Federal Character Principle and National Integration", being a chapter in Amuwo et al. (eds.) (1998), Federalism and Political Restructuring in Nigeria, (Ibadan: Spectrum Books Limited, 1998) p.183.

${ }^{66}$ B.U. Yusufu, "National Cohesion, National Planning and the Construction", in Suleiman et al. (1977) (ed.), Issues in Nigeria Draft Constitution (Zaria: Baraka Press Ltd, 1977), p. 47. 
include freedom from overbearing governmental executive. However, most constitutional scholars are in agreement that liberty includes the freedom from ignorance, poverty and disease. It was for the realization of such a society that the US government enacted the Economic Act of 1964. The Act states by its preamble;

The united states can achieve its full economic and social potential as a nation only if every individual has the opportunity to contribute to the full extent of his capabilities and to participate in the working of our society.It is therefore the policy of the United States to eliminate the paradox of poverty in the midst of plenty in the nation by opening to everyone the opportunity for education and training, the opportunity to work and the opportunity to live in decency and dignity ${ }^{67}$.

Nigeria is a country replete with extreme underdevelopment in the areas of education, health, shelter, food, welfare to mention but few. If the Nigerian nation could embark on a massive industrialization, and welfare schemes, problems associated with poverty and want, ignorance and disease will likely reduce to the minimum. When this happens, democratic process will deepen as political participation will no longer be seen as opportunity to partake in the "national cake" but opportunity to serve. Election expenses will drastically come down and campaigns will cease from being life and death struggle to project ethnic identities but a process of choosing citizens capable of formulating and executing policies that will reflect national objectives.

When politics is no longer seen as a way of making a living by foul or fair means, or as a chance for imposing the whims and caprices of one ethnic group on another, but as a way of rendering selfless services to the country, the tendency to clinch to political position in defiance of public opinion will be eroded to ensure survival of democracy.

\section{Recommendations}

Despite the obvious shortcomings surrounding the practice of federalism in $\mathrm{Ni}$ geria, there seems the general acceptance of the fact that federalism is the best system of government suitable for the country. We need to focus on the critical issues that make federalism to move or that challenge people to work and govern well under a truly federal system. The dominant discussion of Nigeria Federalism is commonly summarized and dismissed in one sentence; Nigeria is a product of conquest and domination and in that case true federalism does not apply to it. While we agreed that colonialism was an aberration; I however do not subscribe to the view that our differences are irreconcilable, such that we cannot live under one federal system. However, how we live and what we do as federating units is what determines the strength of our federal practice.

The all surpassing need for constitutional changes cannot be overemphasised.

${ }^{67}$ Quoted in Henry (1961); The American Federal Government (New York, McGraw, 1961), p. 251. 
I have therefore, suggested the following constitutional changes; these suggested constitutional changes are supposed to address both directly and otherwise the challenges associated with Nigerian federalism. These include;

1) Reduction of the number of the federating units or states/regionalism: Viability shall be the determinant factor in state creation. Therefore the existence or creation of a state shall be determined by a minimum amount or percentage of revenue each can produce. Component states that cannot produce enough should be subsumed into a more viable one.

2) Fiscal federalism: This involves constitutional amendment providing for state control of natural resources. Tax over these resources shall however be made by the States to the Federal Government. Such constitutional amendment will be in line with Fiscal federalism and at the same time put an end to the constant agitation of the oil hosting states and communities.

3) Control of land: Land ownership shall be vested in the various states governments and the communities-not individuals. Let every community control every mineral resources under their land, lease it to the state government and vice versa depending on the applicable tradition in the area. Issues of land tenure, land use and control should all be left to the States. State/Community control over land will require that the Land Use Act be amended and this will reduce the tension between the Federal and the States governments over the issue of land control.

4) Local government: Local Government should remain the responsibility of the States. The current hue and cry over local government creation by the Federal government arises essentially from the fact that they feel it will affect revenue formula and structure of allocation of seats to the Federal legislature. This ought not to be the case if local governments are made purely state affairs. Their activities will be of no consequences for the federal government and polities (such as delimitation of federal constituency) at the federal level. Everything relating to their management and supervision should be left to the State government. In fact Fiscal Federalism entails that states shall manage and control local governments.

5) Revenue allocation: As a result of the foregoing proposals especially on land use, natural resource control and fiscal federalism it is clear that there will be misappropriate revenue accruable to various states of the federation. However, to ease and assist the less economically viable states, there shall be provided a common pool into which shall be paid certain agreed percentage royalty from the proceed of natural resource from the mineral or natural resources producing units of the federation. This pool shall be managed by the Federal Government and shall be distributed to the states or units according to their various needs and or including other conditions as may be determined by the National Assembly.

6) The issue of corruption/embezzlement of public funds Section 308 of the 1999 Constitution, on the immunity of the President, the Vice President, the Governor and the Vice should be amended to ensure that our office holders in- 
cluding the President could be prosecuted for crime. Removal of immunity clause will ensure responsible government.

7) State constitutions: There is need for various states of the federation to have their own constitution that will contain and define what they want and how they intend to go about them. With state constitution it is easy for a state to define matters that are peculiar to it, socially, spiritually, economically and finds ways to addressing them. A state that wishes to have the second generation rights on its Constitution and makes them justiceable can do so. At present, the Federal Constitution is too general and inapplicable in many instances at the state level. It concentrates too many responsibilities in the Federal Government, giving states very few and as such equally giving them an escape route. State Constitution will encourage citizens to become more concerned about what is happening to their state revenue and more appreciative of state promises rather than federal government taking unjust share of revenue, hence all they have is a token for salary and they claim they are unable as such to do much for the people. With state constitution, citizens will think more of how to devise laws that will protect them from bad governance and mismanagement of their resources. State constitution is in line with true federalism.

8) Intergovernmental Relations: For there to be functional federalism, the various agencies of government should also function properly with oversight functions performed by the various agencies of the National Assembly (NASS) and various State Assemblies. Part of the problem arising from the waste, corruption, mismanagement and squander that had characterized various agencies of government is because the National Assembly had not performed strict oversight role over them. At present many of these agencies feel that they are only accountable to the presidency, partly due to the fact that their heads are appointees of the President. Ancillary to this is the judiciary. It is only an effective judiciary that can ensure a true democratic government. Democracy in turn ensures good governance and development. A constitutional amendment strengthening the independent of the judiciary is advocated. Not only shall NASS approve all major appointment of the president, NASS shall also have constitutionally power to remove any erring appointee of the President where the later refuses to do so.

\section{Conclusion}

Federalism as a form of government is best suited for a pluralistic and multicultural society like Nigeria. Its purpose is to enable each group free from interference or control by the others, to govern itself in matters of local concern, leaving matters of common interest to be managed centrally, and those which are of both local and national concern to be administered concurrently. By this, the differing interests and circumstances of the component groups are accommodated while at the same time securing the peace and stability of the country and its survival against the forces of division and conflict inherent in the heterogeneous nature of the society. 
The contemporary conditions and contradictions of the Nigerian federation have been heavily and directly shaped by the federation's colonial origins and the legacies of the country's successive post-independence military regimes. Whilst federalism has brought several nations within the Nigerian polity together, actual federal practice has hardly been able to keep them together happily. To all appearances, political restructuring in a federal polity like Nigeria is needed to achieve certain specific objectives. First, restructuring is meant to serve as a steering mechanism to properly give focus and locus to attempts at collective identity and distributive polities. The aim is to correct perceived structural defects and institutional deformities. Second, political restructuring is intended to lay an institutional foundation for a more just and a more equitable sharing of the political space by multinational groups cohabiting in a federal polity, this strategic objective seems to be the solidifying or perhaps merely engendering of a sense of national community.

Perhaps among others, the more compelling need to revise the 1999 Constitution is with regard to the pooling together of the resources of the federation under the Federal Government and the distribution of the resources subsequently. As has already been indicated, the essential feature of every federal polity is the distribution of sovereign powers, resources inclusive between the central authority and the constituent units.

Nigerian federalism requires fundamental rethinking and indeed, revision. The revision should entail the assertion by the nationality stakeholders of the federation as reflected in their cumulative experiences since the federal system was formally established by the 1954 Lyttleton Constitution. Revision implies freedom for the nationality stakeholders to negotiate new foundations for the system such as: Nigeria should have a new constitution necessary and appropriate for a new restructured federal system, in the sense that the new constitution shall be drafted by democratically elected representatives by Nigerians. The provisions and ideals of the proposed constitution must be given wide publicity thereby giving Nigerians adequate opportunity to study the proposed constitution. This will help to achieve the desired consensus and respect.

There remains a pressing need for a genuine and fundamental restructuring and transformation of our society so as to favour unity against diversity and also to guard against control of the centre by any one of the ethnic groups. Bearing in mind the exigencies of government, this is, taking into consideration, the peculiarities, history, eccentricities of the local conditions of the country fashioning out the constitution which shall incorporate the principle of co-operation and comity. In a multi-ethnically segmented state such as Nigeria, with very complex social and economic problem, the only solution and way forward is to adopt true federalism.

\section{References}

Alameyeseigha, D. (2005). Oil Exploration and Youth Restiveness, the Example of Ba- 
lyelsa State. Tell Magazine No. 16 April 18.

Amah, E .I. (2016a). A Critical Appraisal of the Federal Features of the Nigerian Constitution. Ebonyi State University Law Journal, 7.

Amah, E. I. (2011). A Critical Analysis of the Federal and States Taxing Powers in Nigeria. Journal of Commercial and Contemporary Law, 1.

Amah, E. I. (2013). Nigerian Federalism and the Issue of Resource Ownership and Management: An Appraisal. Confluence Journal of Jurisprudence on International Law, 6, No. 2.

Amah, E. I. (2016b). Federalism, Democracy and Constitutionalism: The Nigerian Experience. Journal of Law, Policy and Globalization, 53.

Amah, E. I. (2017). Nigeria: The Search for Autochthonous Constitution. Beijing Law Review, 8, 141-158. https://doi.org/10.4236/blr.2017.81008

Amuwo, K. et al. (1998). Federalism and Political Restructuring in Nigeria. Ibadan: Spectrum Books Limited.

Anam-Ndu, E. A. (2007). Fiscal Federalism, Resource Control and Violence in the Niger Delta. Being Text of Paper Presented at Center for Minority and Development Studies, Uyo, at the National Association of Seadog's Town Hall Meeting Held at Eden Hotel, Eket on Saturday May 5.

Anthony, E. O. et al. (2004). Federalism and National Integration in Nigeria. Onitsha: Bookpoint Ltd.

Ayua, I. A. et al. (2001). Nigeria: Issues in the 1999 Constitution. Lagos: Nigerian Institute of Advanced Legal Studies.

Darah, G. G. (2003). The Niger Delta Manifesto. Paper Presented for the Delta Peoples Academy Abraka Delta State, at the 3rd All Nigeria Socialist Conference, Benin City, February 20-22.

Dudley, B. (1973). Instability and Political Order: Political Crises in Nigeria. Ibadan: Ibadan University Press.

Dudley, B. J. (1975). Skepticism and Political Virtue. Inaugural Lecture, University of Ibadan.

Ekeh, P. P. et al. (1989). Federal Character and Federalism in Nigeria. Ibadan: Heinemania Books Nigeria Ltd.

Elaigwu, J. I., Longams, P. C., \& Galadima, H. S. (2008). Federalism and Nation Building. National Council of Inter.

Elazar, D. J. (1994). Federal System of the World (p. 3). A Hand Book of Federal, Confederal and Autonomy Arrangements. Harlow: Longman. http://www.jcpa.org/dje/books/fedsysworld-intro.htm

Gwendolen, M. C., \& Patrick, O. M. (1985). African Independence: The First Twenty-Five Years. Bloomington: Indianan University Press.

Henry, F. M. (1961). The American Federal Government. New York, NY: McGraw.

Igwenyi, B. O. (2006). Modern Constitutional Law in Nigeria. Abakaliki: Nwamazi Printing and Publication Company Ltd.

Larry Diamond (1988). Class, Ethnicity and Democracy in Nigeria: The Failure of the First Republic. London: Macmillan Press.

Livingstone, W. S. (1952). A Note on the Feature of Federalism. Political Science Quarterly, 62 .

Mackintosh, J. P. (1962). Federalism in Nigeria. Political Studies, 10, 3. 
https://doi.org/10.1111/j.1467-9248.1962.tb00994.x

Nnoli, O. (1980). Ethnic Politics in Nigeria. Enugu: Fourth Dimension Publishers.

Nwabueze, B. O. (1973). Nigeria under the Presidential Constitution. London: C. Hurst \& Co.

Nwabueze, B. O. (1983). Federalism in Nigeria. London: Sweet and Maxwell.

Nwabueze, B. O. (1995). Constitutional History of Nigeria. Spectrum Books Ltd.

Nwabueze, B. O. (2007). How President Obasanjo Subverted Nigeria’s Federal System. Ibadan: Gold Press Ltd.

Saro-Wiwa, K. (1985). The Guardian.

Suleiman, K. et al. (1977). Issues in Nigeria Draft Constitution. Zaria: Baraka Press Ltd.

Udoma, U. (1994). History and Law of the Constitution of Nigeria. Lagos: Malthouse Press Ltd.

Wheare, K. C. (1963). Federal Government (4th ed.). Oxford: University Press.

Submit or recommend next manuscript to SCIRP and we will provide best service for you:

Accepting pre-submission inquiries through Email, Facebook, LinkedIn, Twitter, etc. A wide selection of journals (inclusive of 9 subjects, more than 200 journals)

Providing 24-hour high-quality service

User-friendly online submission system

Fair and swift peer-review system

Efficient typesetting and proofreading procedure

Display of the result of downloads and visits, as well as the number of cited articles

Maximum dissemination of your research work

Submit your manuscript at: http://papersubmission.scirp.org/

Or contact blr@scirp.org 